\title{
Images of Europeans in the Chinese Woodblock Book Huangqing zhigongtu
}

\author{
N. A. Samoylov, D. I. Mayatskiy
}

For citation: Samoylov N. A., Mayatskiy D. I. Images of Europeans in the Chinese Woodblock Book Huangqing zhigongtu. Vestnik of Saint Petersburg University. History, 2020, vol.65, issue 4, pp. 12591271. https://doi.org/10.21638/11701/spbu02.2020.415

This article explores the Chinese historical and ethnographic work of the second half of the $18^{\text {th }}$ century "Illustrated tributaries of the Qing Empire" ("Huangqing zhigongtu"). This book provides rich material for a systematic analysis of the views of the Chinese about European countries during the reign of the Qing Dynasty (1644-1911). Twenty eight images and descriptions of a number of European nations - Russians, Poles, Hungarians, Swedes, the English, the Dutch, etc. - which were found in the book, have been identified, classified, and analyzed. A range of issues and problems related to the content of the descriptions has been established and compared with the illustrations from the book. The article pays particular attention to identifying and explaining the anthropological and socio-cultural stereotypes that shaped the image of Europeans in China. The authors of this paper have found out that due to Catholic missionaries the Chinese compilers of "Huangqing zhigongtu" must have had enough information about Europe in the first part of the Qing period. Nevertheless, they made a large number of mistakes when describing the geographical location of several nations and relations between some of them. They also misunderstood some habits, traditions or anthropological features of their inhabitants. On the other hand, the compilers were more accurate and precise with regard to political and trade activities of the Europeans in China or near its frontier. Studying the "Huangqing zhigongtu" can shed light not only on important factors that formed the general picture of the Chinese worldview, but also contribute to a better understanding of motives that determined the foreign policy of the Qing Empire.

Keywords: image studies, China and Europe, history of China, cultural contacts, tributaries, Europeans.

Nikolay A. Samoylov - Dr. Sci. (History), Professor, St. Petersburg State University, 7-9, Universitetskaya nab., St. Petersburg, 199034, Russian Federation; n.samoylov@spbu.ru

Николай Анатольевич Самойлов - д-р ист. наук, проф., Санкт-Петербургский государственный университет, Российская Федерация, 199034, Санкт-Петербург, Университетская наб., 7-9; n.samoylov@spbu.ru

Dmitriy I. Mayatskiy - PhD (Philology), Associate Professor, St. Petersburg State University, 7-9, Universitetskaya nab., St. Petersburg, 199034, Russian Federation; d.mayatsky@spbu.ru

Дмитрий Иванович Маяцький - канд. филол. наук, доц., Санкт-Петербургский государственный университет, Российская Федерация, 199034, Санкт-Петербург, Университетская наб., 7-9; d.mayatsky@spbu.ru

The reported study was funded by RFBR, project number 19-09-00218 “The Chinese Historico-Ethnographic Album 'Illustrated Tributaries of the Qing Empire' ('Huangqing zhigongtu') and its Role in Studying the Chinese Worldview on Other Countries and Nations in the mid- $18^{\text {th }}$ Century".

Исследование выполнено при финансовой поддержке РФФИ в рамках научного проекта № 19-09-00218 «Китайский историко-этнографический памятник “Изображения данников правящей династии Цин” (“Хуанцин чжигунту”) и его значение в изучении представлений китайцев о других странах и народах в середине XVIII в.».

(C) St. Petersburg State University, 2020 


\title{
Образы европейцев в китайской ксилографической книге Хуанцин чжигунту
}

\author{
Н. А. Самойлов, Д. И. Маяцкий
}

Для цитирования: Samoylov N. A., Mayatskiy D. I. Images of Europeans in the Chinese Woodblock Book Huangqing zhigongtu // Вестник Санкт-Петербургского университета. История. 2020. Т. 65. Вып. 4. С. 1259-1271. https://doi.org/10.21638/11701/spbu02.2020.415

В статье исследуется китайский историко-этнографический памятник «Изображения данников правящей династии Цин» («Хуанцин чжигунту»), созданный по приказу императора Цяньлуна (1735-1796) во второй половине XVIII в. и хранящийся в фонде китайских рукописей и ксилографов Научной библиотеки им. М. Горького СанктПетербургского государственного университета. На материале данного сочинения проводится системный анализ представлений китайцев о европейских странах и народах в период правления династии Цин (1644-1911). Вычленяются, классифицируются и анализируются содержащиеся в книге изображения и описания ряда европейских народов - русских, поляков, венгров, шведов, англичан, голландцев и др. Приводятся полные переводы на английский язык текстов описаний португальцев, венгров и швейцарцев. Устанавливается круг вопросов и проблем, связанных с содержанием книги. Особое внимание уделяется выявлению и объяснению антропологических и социокультурных стереотипов, формировавших имидж европейцев в Китае. Авторы статьи отмечают, что составители памятника предположительно намеренно охватили далеко не весь европейский регион, посвятив лаконичные и схематические описания лишь нескольким государствам. При этом они нередко допускают фактические неточности, когда отмечают географическое положение отдельных стран, путаются в их названиях или сообщают неверные сведения о характере политических отношений между ними, об антропологических характеристиках и нравах их населения. Вместе с тем составители тяготеют к высокой фактической точности и информативности, когда речь идет о народах, входивших в сферу традиционных геополитических интересов Китая. Подобные наблюдения позволяют авторам прийти к выводу, что китайские императоры проявляли неглубокий интерес к делам географически удаленной от Китая Европы, в большей степени обращая особое внимание на те народы, которые имели с Китаем длительные исторические связи или непосредственные дипломатические контакты. Изучение "Хуанцин чжигунту» позволяет не только выявить важнейшие факторы, формирующие общую картину китайского мировосприятия, но и способствует лучшему пониманию мотивов, определявших внешнюю политику империи Цин.

Ключевые слова: имагология, Китай и Европа, история Китая, культурные контакты, данники, народы Европы.

In accordance with the principles of foreign policy that prevailed in Imperial China, the Chinese emperor was the single legal representative of Heaven on Earth. He acted as an important organizer of the "Under Heaven world" (Tianxia), and his duty also included the obligation to regulate the relationship between the "Middle Kingdom" (Zhong guo) and the so-called "barbarian periphery". The good moral power of "de" (with a hint of sacred grace), sent down by Heaven to Earth through the universal mediator (Emperor $=$ Son of Heaven), was intended to give a rise in esteem not only for the Han people, but also for the "barbarians of the four cardinal points" and establish the ideal order in Tianxia. This led to an urgent need for constant and close attention to maintaining proper order and harmony in the relations between the zone of high civilization (China) and the "barbarians", as well as conducting careful accounting and analysis of these relations, for 
which a whole compendium of various treatises and compositions was created. One of the chief purposes of such documents was to justify and to state the world-forming functions of the emperor of China.

In this context, the so-called "tributary system" (when any embassy arriving from abroad to the court of the Chinese monarch, or, simply, any foreigner, could be considered as a carrier of tribute) was an integral part of the harmony of the Universe. According to official ideological guidelines, this system was designed to serve as confirmation of the power and virtue of the emperor as the ruler of the "Under Heaven world".

After the establishment of its rule over China in the $17^{\text {th }}$ century, the Manchu Qing Dynasty (1644-1911) with the help of military forces significantly expanded the borders of China. It annexed vast territories in Central and North-East Asia and sought to impose actual tributary relations with many of its neighbors. The largest territorial acquisitions were made during 133 years of the reign of three emperors: Kangxi (1662-1722), Yongzheng (1723-1735) and Qianlong (1736-1795). At that time the Qing Empire expanded to the greatest extent in Chinese history and reached the peak of its power. In the middle of the $18^{\text {th }}$ century it was a huge state with a large and multinational population.

From the preceding Ming Dynasty (1369-1644) the Qing rulers borrowed a detailed reception ceremony for embassies or envoys from other states. The fact of arrival in the capital of a foreign embassy was a priori regarded as recognition of vassal dependence on the Qing Empire, and all diplomatic gifts were referred to in Chinese documents as nothing more than a "tribute". In 1656, a Dutch envoy arrived in the capital of the Qing Empire. In connection with this event, the Office of Rituals ( $L i b u$ ) presented a report saying: "The Dutch state has not paid tribute before. Now their envoy has arrived at the court. Truly, it is the result of [spreading our] valor and civilization. Concerned that [the path of the envoy] was too far and dangerous, we allow [the Dutch people] to pay tribute once every five years, delivering [it] through Guangdong [province]"'. Although at that time, Holland certainly did not send any tribute to the Qing emperor, the arrival of the Dutch envoy was seen as the evidence that the Netherlands recognized its status as a vassal of China.

At the same time, it should be noted that due to the active border expansion, Chinese perceptions of the presence of other countries and peoples in Tianxia also expanded significantly. The concept of "Barbarians of the Four Cardinal Points" was substantially diversified. In the $18^{\text {th }}$ century, several writings containing information about the "overseas" countries and their inhabitants began to appear in China. In addition, the $18^{\text {th }}$ century was a period of growing socio-cultural interaction between Qing China and Western countries, although the process certainly took place in very limited forms: trade relations were established, acquaintance with European science started, Sino-European style was introduced into applied art (albeit on a small scale), Catholic missionaries worked in China. At the same time, contacts with Russia developed, and not only in the field of trade.

Thus, the concept of tributary relations and its actual implementation in nderwent serious changes in Qing China in the $18^{\text {th }}$ century. On the one hand, attempts to virtually apply this doctrine in practice intensified. On the other hand, a large number of countries and peoples entered the orbit of external relations with the Qing Empire that were not ready to even formally fit into the system of the traditional Chinese World Order.

${ }^{1}$ Da Qing Shizu zhang huangdi shilu (Chronicle of the reign of Emperor Shizu of the great Qing Dynasty). Tokyo, 1937. Chapter 102. P.22a (Quoted from: Vneshniaia politika gosudarstva Qing v 17 veke / pod red. L. I. Dumana. Moscow, 1977. P. 53). 
"Huangqing zhigongtu". In the Oriental Department of St. Petersburg State University Academic Library there are two identical xylographic editions of the Chinese cultural and ethnographic work "Illustrated tributaries of the Qing Empire" ("Huangqing zhigongtu", both copies have the same library position code: Xyl. 348)2. The book was created in 1751-1763 and its woodblock printed version appeared in the 1780s by order of the sixth emperor of the Qing dynasty - Qianlong (1735-1796). The album contains unique visual and textual materials, revealing the views of the Chinese about the countries and peoples of the world known to them at that time.

Nowadays, the book "Huangqing zhigongtu" is still poorly researched in Russian and foreign scholarship. A comprehensive review of studies on the subject of the monument can be seen in a special article by Anna M. Kharitonova ${ }^{3}$. We can argue that the comprehensive study and translation of the work into a European language first began in 2019 at the Faculty of Asian and African Studies of St. Petersburg State University. Several sinologists of the faculty (Nikolay A. Samoylov, Dmitry I. Mayatsky, Nadezhda A.Somkina, Tatyana S. Mironova, Marina V. Cherevko and Anna M. Kharitonova) have already prepared and issued a number of publications ${ }^{4}$.

"Huangqing zhigongtu" is a huge book consisting of nine volumes (ben). Each volume includes a table of contents, monochrome illustrations of individual figures representing different peoples of the world and commentaries to these illustrations. Additionally, the first volume has introductory articles outlining the circumstances of the creation of the book, containing information about the publishers and poems in honor of this event.

A total of 598 drawings with images of representatives of more than two hundred peoples who inhabited the territory of the Qing Empire, the lands of neighboring states and countries that had political, commercial, or other ties with China were presented in "Huangqing zhigongtu". Some countries and peoples had no contacts with China, however, some information about them was available to the Chinese from various indirect

${ }^{2}$ Four editions of the book are also available at the Institute of Oriental Manuscripts of the Russian Academy of Sciences (library position codes: E-42, E-43, E-179, Д-284). See: Katalog fonda kitaiskikh ksilografov Instituta vostokovedeniia AN SSSR / sost. B. B. Vakhtin, I. S. Gurevich i dr.: v 3 t. Vol. 1. Moscow, 1973. P. 291-293.

Two editions are in Russian National Library: Catalogue des manuscrits et xylographes orientaux de la Bibliothèque impériale publique de Saint-Pétersbourg / ed. par B. Dorn et R. Rost. Saint-Pétersbourg, 1852. P. 604, 662 .

${ }^{3}$ Kharitonova A.M. Istoriia izucheniia kitaiskogo ksilograficheskogo pamiatnika "Izobrazheniia dannikov praviashchei dinastii Qing" // Uchenye zapiski Petrozavodskogo gosudarstvennogo universiteta. 2019. No. 3. P. 43-50.

${ }^{4}$ Samoylov N. A., Mayatskiy D. I. Kitaiskii istoriko-etnograficheskii pamiatnik "Izobrazheniia dannikov praviashchei dinastii Qing": Predystoriia sozdaniia i sotsiokul'turnoe znachenie // Nauchnyi dialog. 2019. No. 9. P. 437-455; Mayatskiy D. I. Problema identifikatsii gosudarstv "Da-xiyang-guo" i "Xiao-xiyang-guo" v "Izobrazheniiakh dannikov praviashchei dinastii Qing" // Uchenye zapiski Petrozavodskogo gosudarstvennogo universiteta. 2019. No. 8 (185). P.23-30; Mironova T.S. Etnograficheskie svedeniia o nekotorykh sosednikh s Kitaem narodakh v ksilograficheskom al'bome "Izobrazhenie dannikov praviashchei dinastii Qing” (17 v.) // Rossiia - Kitai: istoriia i kul'tura. Sbornik statei i dokladov uchastnikov 12 mezhdunarodnoi nauchno-prakticheskoi konferentsii. Kazan', 2019. P.333-338; Somkina N.A. "Izobrazheniia dannikov praviashchei dinastii Qing" ("Huangqing zhigongtu") kak istochnik svedenii o Tibete v 18 veke // Rossiia Kitai: istoriia i kul'tura. P.450-459; Somkina N.A. "Izobrazheniia dannikov praviashchei dinastii Qing" ("Huangqing zhigongtu") kak istochnik svedenii o Tsentral'noi Azii v 18 veke, tsz. II // Sovremennye vostokovedcheskie issledovaniia, 2019. Vol. 1, no. 4. P. 85-107; Cherevko M. V. Gosudarstva Iugo-Vostochnoi i Vostochnoi Azii v istoriko-etnograficheskom pamiatnike 18 veka "Huangqing zhigongtu" 皇清職貢圖 (“Izobrazheniia dannikov praviashchei dinastii Qing”) // Rossiia - Kitai: istoriia i kul’tura. P. 526-533. 
sources (for example, the messages or works of European missionaries who lived in Beijing) and was also included in the album.

In this article, we intend to examine a particular set of book illustrations depicting Europeans (including the inhabitants of Europe and the European population of the overseas colonies) as well as to study captions to them and short descriptions. Our goal is to establish the features of the images and descriptions of Europeans and their countries in "Huangqing zhigongtu"; to understand what knowledge of Europe the inhabitants of the Middle Kingdom (China) possessed in the mid-18 ${ }^{\text {th }}$ century.

Composition and organization of Europeans' images in the "Huangqing zhigongtu". In "Huangqing zhigongtu" there are 28 drawings relating to Europeans. All of them are presented in the first volume of the book and have the following titles ${ }^{5}$ marked in each picture in the upper right corner:

1. “A barbarian from a state of the Great Western Ocean” (大西洋国夷人).

2. “A barbarian's wife from a state of the Great Western Ocean” (大西洋国夷妇).

3. “A barbarian from Helvetian ${ }^{6}$ province of the Great Western Ocean” (大西洋合勒 未祭亚省夷人).

4. “A barbarian's wife from Helvetian province of the Great Western Ocean” (大西洋 合勒未祭亚省夷妇).

5. “A barbarian from the Hungarian state of the Great Western Ocean” (大西洋翁加 里亚国夷人).

6. “A barbarian's wife from the Hungarian state of the Great Western Ocean” (大西洋 翁加里亚国夷妇).

7. “A barbarian from the Polish state of the Great Western Ocean” (大西洋波罗泥亚 国夷人).

8. “A barbarian's wife from the Polish state of the Great Western Ocean” (大西洋波 罗泥亚国夷妇).

9. “A black slave from a state of the Great Western Ocean” (大西洋国黑鬼奴).

10. “A barbarian's wife from a state of the Great Western Ocean” (大西洋国黑鬼奴 妇).

11. “A monk from a state of the Great Western Ocean” (大西洋国夷僧).

12. “A nun from a state of the Great Western Ocean” (大西洋国女尼).

13. “A barbarian from a state of the Small Western Ocean” (小西洋国夷人).

14. “A barbarian's wife from a state of the Small Western Ocean” (小西洋国夷妇).

15. “A barbarian from the English state” (英吉利国夷人).

16. “A barbarian's wife from the English state” (英吉利国夷妇).

17. “A barbarian from the French state" (法兰西国夷人).

18. “A barbarian's wife from the French state” (法兰西国夷妇).

19. “A barbarian from the Swedish state” (瑞国夷人).

20. “A barbarian's wife from the Swedish state” (瑞国夷妇).

21. “A barbarian from the Dutch state" (荷兰国夷人).

22. “A barbarian's wife from the Dutch state” (荷兰国夷妇).

23. “A barbarian official from the Russian state” (俄罗斯国夷官).

${ }_{5}$ The listing of the titles of the illustrations repeats the sequence given in the "Huangqing zhigongtu".

${ }^{6}$ A region in the northwestern part of Switzerland. A short article by Alfred Steinman is dedicated to these images. See: Steinmann A. Die Schweiz in chinesischer Darstellung. Ein Kuriosum chinesischer Geschichtsschreibung aus dem 18. Jahrhundert // Sinologica. 1953. Vol.3, no. 3. P.97-99. 
24. “A barbarian official's wife from the Russian state” (俄罗斯国官妇).

25. "A barbarian from the Russian state" (俄罗斯国夷人).

26. “A barbarian's wife from the Russian state” (俄罗斯国夷妇).

27. “A barbarian from the Lüsong state" (吕宋国夷人).

28. “A barbarian’s wife from the Lüsong state” (吕宋国夷妇).

In eight cases, residents of two hypothetical states are shown. The first is called the "state of the Great Western Ocean" (six illustrations), and the second - the "state of the Small Western Ocean" (two illustrations). These are very hard to identify. On the "Complete Map of All Countries" (“Kunyu wanguo quantu” 坤輿萬國全圖), which was compiled in 1602 for the needs of Chinese emperor Wanli (1572-1620) by the Italian missionary Matteo Ricci (1552-1610), we can find all the oceans, continents and countries known by that time. "The Great Western Ocean" on it designates the Atlantic Ocean, and "the Small Ocean" designates the Indian Ocean ${ }^{8}$. Since the commentary to the first of these countries mentions the natives of Italy (Matteo Ricci and an ambassador of Pope Benedict XIII, 1724-1730) ${ }^{9}$ and those of Portugal (ambassador of King Joao V, 1706-1750) ${ }^{10}$, and it also reports that its residents have European facial features, wear European clothes and settle in Macau ${ }^{11}$ in China, it is logical to assume that this state should be either Portugal or the Spanish Empire at the time of its greatest power in the $17^{\text {th }}$ century, when Portugal and most of Italy were parts of it. The "state of the Small Western Ocean" is said to be subject to the "country of the Great Western Ocean". The people of the both countries are depicted very much alike (in facial features and clothing) ${ }^{12}$. Based on this, it becomes clear that the commentary speaks about a Portuguese or Spanish colony in the Indian Ocean.

Two pictures are dedicated to the settlers of the Spanish colony in the Philippines (residents of the island of Luzon). In other cases, images of people belong to eight specific countries or regions of Europe - Switzerland, Hungary, Poland, Great Britain, France (in reality, the text describes Portugal), Sweden, the Netherlands, and Russia.

A study of the structure in the first volume of "Huangqing zhigongtu" showed that there was no clear logic in the order of presenting the pictures. The compilers seemed to adhere to the geographical principle, but sometimes it is violated. The images we examine are divided into three groups. One is introduced after the illustrations of the Lao and Burmese people. This part ends with an illustration of a Swedish woman, unpredictably followed by pictures of the Japanese, Indonesians and Malays (with the Brunei Malays). Further, the compilers insert a second group of illustrations, consisting of the Dutch and Russians. Then, they again turn to the peoples of Southeast Asia, among which the European inhabitants of the Philippines (Luzon Island) are mentioned.

7 The largest of the Philippine Islands. In "Huangqing zhigongtu", appears as a generic name for the Philippines.

${ }^{8}$ Li Madou (Matteo Ricci). Kunyu wanguo quantu (Complete Map of All Countries in the World). Beijing, 1602-1605. - The Japanese copy of this map, that was made in 1605, was used by us. It is available here: URL: https://ru.wikipedia.org/wiki/\%D0\%9A\%D0\%B0\%D1\%80\%D1\%82\%D0\%B0 \%D0\%9C\%D0\%B0\%D1\%82\%D1\%82\%D0\%B5\%D0\%BE_ \%D0\%A0\%D0\%B8\%D1\%87\%D1\%87\%D0\%B8 /media/\%D0\%A4\%D0\%B0\%D0\%B9\%D0\%BB:Kunyu_Wanguo_Quantu_(\%E5\%9D\%A4\%E8\%BC\%BF\% E8\%90\%AC\%E5\%9C\%8B\%E5\%85\%A8\%E5\%9C\%96).jpg (accessed: 30.03.2020).

9 See: Huangqing zhigongtu (Illustrated tributaries of the Qing Empire). Juan 1. P.33-a.

${ }^{10}$ Ibid.

11 Ibid.

12 Ibid. P. 45-a. 
It is also easy to notice that the list of the European states described in the book is rather scarce. The authors did not supply special illustrations and annotations to many other peoples of Europe - Italians, Germans, Serbs, Austrians, etc. This is despite the fact that representatives of some of them (for example, Matteo Ricci and legates of the Pope), as well as a number of names of other European lands in the text are mentioned. For example, in the text of the book the authors sometimes refer to "Germany" (for instance, they write about Switzerland that it is part of Germany ${ }^{13}$, or about Poland - that it is located "to the east of Germany"14). "Portugal"15, "Italy"16 and "Bosnia" (in the text about Hungary ${ }^{17}$ ) are also mentioned. Ignoring peoples and countries which often came into contact with the Chinese, the compilers found it somehow important to pay attention to other nations, sometimes rather small and without obvious ties with China (the Swiss, Hungarians, Poles).

At first glance, this situation could be explained by the scarcity of information about Europe available to the compilers of the "Huangqing zhigongtu". Such explanation, though, is likely to be only partly true since there is reason to believe that the Chinese in the book wrote much less about Europeans than they actually knew. They could have known more about Germany because its geographical position is mentioned several times. They probably knew more about Italy and Portugal because they had direct long-term contacts with Italians and Portuguese (Catholic missionaries, residents of Beijing and Macau). The prominent Russian sinologist and head of the $9^{\text {th }}$ Russian Ecclesiastical Mission in China, Archmandrite Iakinf (Nikita Ya. Bichurin, 1777-1853), who specially studied the history of knowledge about Europe in China, wrote that by the middle of the Qing dynasty the Chinese, thanks to the Jesuits missionaries, had information about 70 European countries and territories, including Portugal, Spain, France, Italy, England, Germany, Holland, Poland, Hungary, Denmark, Norway, Sweden, Finland, Greece, etc. ${ }^{18}$ Moreover, the above-mentioned Matteo Ricci map was also available to the Chinese. Many European lands and cities were marked on it in detail. Emperor Wanli (1572-1620) even ordered to replicate this map in many copies.

In our opinion, one of the main possible reasons for the narrowing of scale of European part in the album could be the initial lack of intention among the compilers to make the book as complete as possible in relation to the countries of the world that were distant from China geographically and did not represent significant political interest to it historically.

Peculiarities of illustrations and descriptions of Europeans in "Huangqing zhigongtu". Having outlined the illustrations of Europeans and the commentaries to the images, we can point out a number of the following observations:

1. All the images are divided into pairs. As a rule, for each country or region, two figures are given - one male and one female. Obviously, they were supposed to demonstrate images of typical representatives of the lands examined. The exception was made for inhabitants of the "state of the Great Western Ocean" with six illustrations (illustrations

13 Ibid. P. 35-a.

14 Ibid. P. 39-a.

15 Ibid. P.33-a.

16 Ibid.

17 Ibid. P. 37-a.

18 Bichurin N. Ia. (Iakinf). Svedeniia o Evrope, soobshchennye kitaitsam katolicheskimi veroispovednikami // Otechestvennye zapiski. 1845. Vol. 40, no. 6. Section 8. P.91-97. 
of slaves and clergy were added here), and for Russians with four drawings (images of an official and his wife were added).

2. To denote the inhabitants of European countries, the authors use the hieroglyph “yi” 夷, which is usually translated as "a barbarian", but it also could have the meaning of "foreigners/aliens". In ancient China, this word was used to refer to non-Chinese nationalities living round the Chinese state. It is possible that it refers to peoples who were not really dependent on the Qing empire. The only exception were the Dutch, who received an additional nickname in their description - "red-haired barbarians" ("hong mao fan" 红 毛番). It contains the hieroglyph "fan" ("barbarians"), which has a pronounced contemptuous and pejorative connotation. This designation was usually applied to wild savages or uncivilized peoples. The Dutch could receive this nick name because of their plundering raids on the Chinese coast or attacks on the trade ships at sea off the coast of China. They also captured the island of Taiwan, which was held by them from 1624 to 1662 . All of these activities are reported in the description ${ }^{19}$.

3. In some cases, images of Europeans were created in a realistic and accurate way. The desire of the creators to meticulously convey ethnic features of the typical faces and costumes of the characters is evident. In this regard, the illustrations of the Swiss, Hungarians and Poles who are dressed in recognizably traditional costumes look convincing and realistic. In other cases, the authors depart from accuracy; the faces of Europeans (for example, Russians) can acquire Asian features. Their outfits also look very oversimplified. The same type of clothing is typical of representatives of Northern, Western (except the Swiss) and Southern Europe. For example, men's outfit in these countries includes a standard set of items - a cocked hat, a wig, a camisole, culottes, stockings, shoes, a sword and a cane.

The authors suggest that the compilers of the book could adhere to the principle of observing authenticity in the images of Europeans when they had a clear idea about them obtained in the course of personal contacts or acquaintance with the materials (which may have been provided by the Catholic missionaries) understandable to the Chinese. In those cases when the authors were embarrassed or failed to understand something, it was more convenient for them to create approximate schematic images.

4. The commentaries to the illustrations give us brief and fragmentary information on the geographical location of the country, its history and (if there were any precedents) on tributary and other contacts with China. Additionally, some ethnographic features of the population are noted regarding their clothing, occupations, food, customs, habits etc. Sometimes this data may contain factual mistakes. For example, Hungary is said to be located to the south of Bosnia ${ }^{20}$. England and Sweden are designated there as territories dependent on the Netherlands ${ }^{21}$. France ("Falangxi") and Portugal ("Folangji") are confused due to the similarity in the transcription of names. As a result, the Portuguese are described under the illustrations which undoubtedly demonstrate the French. Moreover, the compilers believe that French people had been Buddhists before they adopted Catholicism ${ }^{22}$.

19 Ming shi (History of Ming). Juan 325. See also: Tang Jintai. Qianjin Fuermosha: Shiqi shiji dahanghai niandai de Taiwan (Formosa is straight ahead: Taiwan in the era of great sea discoveries of $17^{\text {th }}$ century). Taibei, 2001. P. 124.

20 Ibid. P. 37-a.

21 Ibid. P. 47-a, 51-a.

22 Ibid. P. 49-a. 
All this indicate that the Chinese did not take much interest in the geography of Europe and, besides, had hardly any understanding of European political affairs since European countries were too far from China. Chinese travelers or geographers did not reach them, nor did they write about them in their books, and these lands historically never entered the zone of traditional political interests of the Chinese state. For this reason, the compilers were mainly concerned about the activities of Europeans near the Chinese borders, in the countries of the Far East and Southeast Asia, which paid China a tribute since the ancient times and had trade relations with it. Such events are thoroughly described, filled with strikingly accurate facts. The following passage about Portugal (Fig. 1,2) can serve as a typical example of such bias: "Falanxi [(France)] sometimes is called "Folangxi" [(France)]. [In the era of] Ming [(1369-1644)] it was the country of Folangji [(Portugal)]. Since antiquity, had no contact with the Central State. In the years of Zhengde [(1506-1521)] they sent an ambassador asking for a land award, but were not successful. Later without obtaining permission they occupied Macau in the mountains of Xiangshan [(Xianglushan)]. Their people are willful and skillful in use of weapons. Many times defeated Lüsong [(Luzon Island, Philippines)] and Manzijia [(Malacca)]. They together with the red-haired [(the Dutch)] divided Mailuoju [(Moluccas in Indonesia)] into two parts and established total control over the benefits of maritime trade in Fujian and Guangdong. Once they worshiped the Buddha, but later began to believe the Teaching of Heavenly Father [(Catholicism)]. Therefore, trade in Macau was taken over by the [people] from the Great Western Ocean. Their leader, who lives in Lüsong, recently fought with the red-haired English for domination, but Falanxi was a little weaker than them. People wear white shawls and black felt hats, also consider it polite to take off their hats. Their clothes are about the same as in the countries of the Great and Small Western Oceans [(India)] or in Lüsong. The outfits of women are also very similar to those in all countries of the Netherlands" 23 .

In this passage the historical aspect is more detailed, because, in fact, it was an issue of invasion in China and interruption into the zone of its interests in the region. The compilers create an amusing confusion - not only in the names of France and

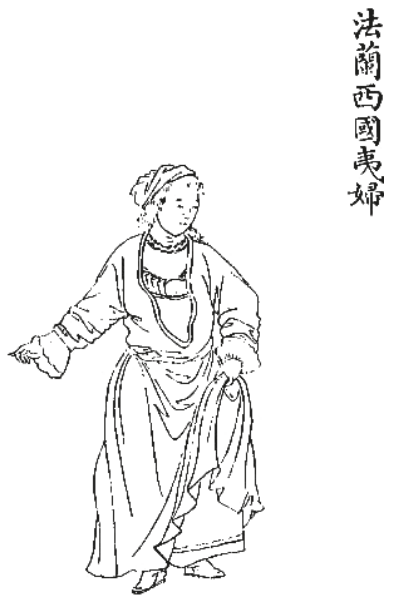

Fig. 2. "A barbarian's wife from the French state"

[Huangqing zhigongtu. Vol. 1. P.38-b]

${ }^{23}$ Ibid. P. 49-a, 49-b. 
Portugal, but also in historical facts, which show that the compilers get France mixed up with Portugal and Spain, and Britain - with the Netherlands. Partly this misunderstanding was caused by Matteo Ricci who referred to Portugal as "Folangji" 拂朗机 on his map, and to France - as "Folangcha" 拂朗察 ${ }^{24}$. Despite the confusion, it is clear that the country to which the description is devoted is still Portugal.

To clarify the contents of the passage above, it is necessary to examine the history of the events mentioned there. In the history of discovering Asia by Europeans, the Portuguese were the first to come to China from the Old World. This happened in 1513 (just during the Zhengde years, as the compilers say), when a traveler Jorge Alvares (d. in 1521) arrived there from Malacca and landed on one of the islands in the Pearl River Delta. Alvares asked the Chinese authorities for a permission to establish a trading settlement there, but was refused and had to withdraw with nothing. In the same year, another Portuguese navigator, Diogo Lopes de Sequeira (1465-1530) also without any success tried to create a colony in Guangdong (in the Thunmun area of modern Hong Kong) ${ }^{25}$. Later, many similar attempts accompanied by armed clashes with the Chinese were made by the Portuguese until, by the 1580s, they were finally allowed by the Chinese Emperor to establish a trading post in Macau. Apparently, due to their perseverance and militancy, the compilers of "Huangqing zhigongtu" described them as "willful and skillful in use of weapons".

The Philippine Islands were first discovered by the Spaniards in 1521. Owing to Magellan's unsuccessful adventure, they were expelled from there, but later returned. The first permanent Spanish settlement was founded in the Philippines in 1565, it being Fort San Miguel. Since then up until 1898, the archipelago had been under the colonial control of Spain. At the time when Matteo Ricci was creating his world map for the Chinese, Portugal was part of Spain (the union lasted from 1580 to 1640). This is the reason why the Chinese might have had the impression that Europeans who settled in Macau and the Philippines were people from the same country.

The Moluccas were discovered by the Portuguese in 1512 and were controlled by them up to 1663 until these islands were occupied by the Dutch.

Malacca from 1511 to 1641 belonged to the Portuguese; then, from 1641 to 1795 - to the Dutch. In 1795 it was ceded to the British. In 1762 British troops invaded the Philippines and, after winning the battle of Manila, kept their fleet on the islands for two years. Under the terms of the Paris Peace Treaty of 1763, their troops were removed from there.

Thus, we see that the description mainly reflects real events. However, the events were sometimes associated with other states.

5. The illustrations and texts commenting on them often contain details reflecting the stereotypes with regard to certain peoples, which prevailed among the compilers. Sometimes these are understandable and can be related to the ethnic groups described. In other cases, they can hardly be given any reasonable explanation. For example, an Englishman is depicted with a vessel in his hand, and the description refers to the passion of men in his country for drinking alcohol. An English lady in the picture tightens her waist and sniffs tobacco from a snuff box ${ }^{26}$. Poles are attributed a physical resemblance to Mongols, they

\footnotetext{
24 Li Madou. Kunyu wanguo quantu. 1602-1605.

25 Zhang Yibing. Shenzhen gudai jianshi (A brief history of the ancient Shenzhen). Beijing, 1997.

${ }^{26}$ Huangqing zhigongtu. Juan 1. P. 47-a.
} P. $148-155$. 
wear fur hats, show love for fencing and having fun with bears ${ }^{27}$. Russians live in regions the names of which contain letters "sk", wear warm clothes, drink alcohol, eat wheat cakes. They are boastful, profess Buddhism, observe a long fast every year ${ }^{28}$ etc.

Some facts are clearly reconsidered by the Chinese through the prism of their own culture. Occasionally, this leads to ridiculous descriptions. For example, they write about Hungarians (Fig. 3, 4) in this way: "The Hungarian state is located to the south of Bosnia. Its population resembles the Mongols. The clothes are very short. Pants and stockings fit snugly like bandages. They are very smart, honor etiquette. From childhood, they learn to ride their short-necked fast horses. They always wear a curved sword which is four chi $(120 \mathrm{~cm})$ long. Everyone knows how to do tricks on a horse. Women are trained in literacy and are skillful in needlework. When they go outside, they must cover their face with a gas veil. [The land] is very rich in resources. Cows and sheep can be delivered to other lands. Gold, silver, copper, iron and other metals are mined - they don't end there" 29 .

This description, similarly to many others, is concise and, to some extent, accurate. However, in some parts it contains obvious ridiculous errors and misconceptions. Two assumptions can be made with a view to explaining this phenomenon. Firstly, the Chinese did not contact the Hungarians until the second half of the $18^{\text {th }}$ century (this is also indicated by the lack of facts mentioning sending any "tribute" to China), and they presumably learned about them through European intermediaries. This is evidenced by a realistic illustration and a number of details that clearly reflect the national characteristics of the Hungarians. Secondly, due to the nomadic past of the Hungarians, the compilers found them to be quite similar to Mongol nomads, who were well-known to the Chinese. Such perception could provoke the compilers to liken the people described to the Mongols. Therefore, we see in the descriptions of Hungarians Mongolian features, Mongolian horses with short necks, horseback riding trainings in childhood, the men's craving

27 Ibid. P. 39-a.

28 Ibid. P. 63-a, 63-b.

29 Ibid. P. 37-a. 


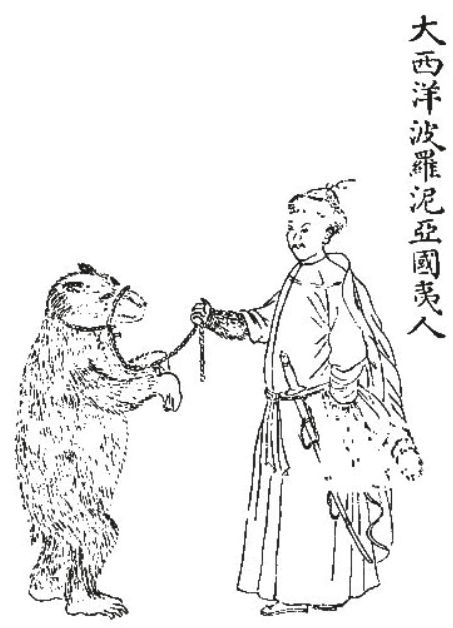

Fig. 5. "A barbarian from the Polish state of the Great Western Ocean" [Huangqing zhigongtu. Vol. 1. P.38-a]

for horse riding, their constant wearing of weapons resembling Mongolian sabers.

Comments about the Swiss tell us: "The province of Helvetia is subordinate to the state of Germany. The people there are powerful and strong, highly value debt and devotion. If they see good attitude, they will certainly pay for it. Public schools are opened in [their] villages. More than half of the population are well trained in military affairs. Often go to other countries. Foreign rulers usually hire them as bodyguards. In their lands there are many mountains. In the winter months it is very cold. They build solid houses. Their women are virtuous and unsophisticated, skilled in delicate work and able to weave wool with gold with their bare hands without use of looms. Their fabrics are the lightest and thinnest. Gold is mined in the earth. They dig up wells and always find gold nuggets, which are often found also at the bottom of rivers. In the mountains there are deer, hares, and leopards; at home breed cows give them delicacies" 30 .

By and large, with the exception of the erroneous inclusion of Switzerland in the German lands (as we know, Switzerland has been an independent state since 1291), the rest of the information about it and its inhabitants is quite recognizable and looks reliable. We suggest that the compilers of the album resorted to reliable non-Chinese sources, probably obtained from European missionaries. Nevertheless, some information was reshaped by the authors in accordance with their cultural background. Ore mines are called "wells", and dairy products - "delicacies". Indeed, in traditional Chinese cuisine, milk is not used, and no products are made from it, even the language of that period contained no special words that would indicate the concepts associated with milk and dairy products. Therefore, in all likelihood the Chinese compilers must have remained unaware of the "delicacies" that are given by cows.

7. The images and descriptions of the East European peoples - Hungarians (Fig. 3, 4), Poles (Fig. 5), and Russians - differ from other Europeans and are colored by the perception of the compilers who associated them with the Asian population. Their clothes, appearance and lifestyle, in the view of the Chinese, were unlike those of the rest of Europe. This observation suggests that East Europeans were perceived by the Chinese as anthropologically and culturally separate (or markedly different) from the other parts of Europe.

Despite laconicism and some inaccuracies and curiosities, the album was a significant achievement of Chinese cultural knowledge of that time. It testifies that in the context of intensifying contacts with representatives of foreign states the Chinese tended to rely on the information available to them, to generalize and structure, as much as possible, an integral cultural and geographical picture of the then world. However, this was done in full accordance with the traditional Chinese image of the World and Chinese perceptions

${ }^{30}$ Huangqing zhigongtu. Juan 1. P.35-a. 
of relationships between the "Middle Kingdom" and the "Barbarians of the Four Cardinal Points". Crucial transformation of these ideas did not occur until late $19^{\text {th }}$ century, when, during the Opium Wars, the Chinese World Order was completely destroyed, and the Qing Empire was forcibly involved into the Modern system of international relations.

\section{References}

Bichurin N. Ia. Information about Europe, which was reported to the Chinese by Catholic monks. Otechestvennye zapiski, 1845, vol.40, no. 6, section 8, pp.91-97. (In Russian)

Cherevko M. V. States of Southeast and East Asia in the historical and ethnographic monument of the $18^{\text {th }}$ century "Illustrated tributaries of the Qing Empire". Rossiia - Kitai: istoriia i kul'tura. Sbornik statei i dokladov uchastnikov 12 mezhdunarodnoi nauchno-prakticheskoi konferentsii. Kazan, "Feng" Publishing House of the Academy of Sciences of the Republic of Tatarstan, 2019, pp. 526-533. (In Russian)

Kharitonova A. M. The history of the study of the Chinese woodcut monument "Images of tributaries of the ruling Qing Dynasty”. Uchenye zapiski Petrozavodskogo gosudarstvennogo universiteta, 2019, no.3, pp. 43-50. (In Russian)

Mayatskiy D. I. The problem of identifying the states of "Da-xiyang-guo" and "Xiao-xiyang-guo" in "Illustrated tributaries of the Qing Empire". Uchenye zapiski Petrozavodskogo gosudarstvennogo universiteta, 2019, no. 8 (185), pp. 23-30. (In Russian)

Mironova T.S. Ethnographic information about some peoples neighboring China in the xylographic album "Illustrated tributaries of the Qing Empire" (18 ${ }^{\text {th }}$ century). Rossiia - Kitai: istoriia i kultura. Sbornik statei i dokladov uchastnikov 12 mezhdunarodnoi nauchno-prakticheskoi konferentsii. Kazan', "Feng" Publishing House of the Academy of Sciences of the Republic of Tatarstan, 2019, pp.333-338. (In Russian)

Samoylov N. A., Mayatskiy D. I. Chinese historical and ethnographic monument "Illustrated tributaries of the Qing Empire": The background to the creation and socio-cultural significance. Nauchnyi dialog, 2019, no. 9, pp. 437-455. (In Russian)

Somkina N. A. "Illustrated tributaries of the Qing Empire" ("Huangqing zhigongtu") as a source of information about Tibet in the $18^{\text {th }}$ century. Rossiia - Kitai: istoriia i kul'tura. Sbornik statei $i$ dokladov uchastnikov 12 mezhdunarodnoi nauchno-prakticheskoi konferentsii. Kazan', "Feng" Publishing House of the Academy of Sciences of the Republic of Tatarstan, 2019, pp.450-459. (In Russian)

Somkina N. A. "Illustrated tributaries of the Qing Empire" ("Huangqing zhigongtu") as a source of information about Central Asia in $18^{\text {th }}$ century, tsz. II. Sovremennye vostokovedcheskie issledovaniia, 2019, vol. 1, no. 4, pp. 85-107. (In Russian)

Steinmann A. Die Schweiz in chinesischer Darstellung. Ein Kuriosum chinesischer Geschichtsschreibung aus dem 18. Jahrhundert. Sinologica, 1953, vol. 3, no. 3, pp.97-99.

Tang Jintai. Going forward to Formosa: Taiwan in the seventeenth century's great voyage. Taibei, Maotouying, 2001, 124 p. (In Chinese)

Zhang Yibing. A brief history of Shenzhen in ancient times. Beijing, Wenwu chubanshe, 1997, 207 p. (In Chinese)

Статья поступила в редакцию 30 марта 2020 г.

Рекомендована в печать 9 сентября 2020 г.

Received: March 30, 2020

Accepted: September 9, 2020 